\title{
Nutrient $(N, P, K)$ use efficiency and nitrogen balance in a bioenergy plantation of Populus deltoides clone Lux in San Piero A Grado (Pisa), Italy
}

\author{
Eficiencia en el uso de nutrientes $(\mathrm{N}, \mathrm{P}, \mathrm{K})$ y balance de nitrógeno en una plantación bioenergética \\ de Populus deltoides clon Lux en San Piero A Grado (Pisa)
}

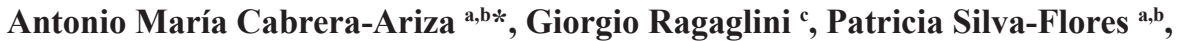 \\ Óscar Bustos-Letelier ${ }^{d}$, Rómulo Santelices-Moya ${ }^{\text {b }}$ \\ *Corresponding author: a Universidad Católica del Maule, Vicerrectoría de Investigación y Postgrado, \\ Centro de Investigaciones y Estudios Avanzados del Maule (CIEAM), Avenida San Miguel 3605, Talca, Chile, \\ tel.: +56-071-2413728, acabrera@ucm.cl \\ ${ }^{\mathrm{b}}$ Universidad Católica del Maule, Facultad de Ciencias Agrarias y Forestales, Centro de Desarrollo del Secano, \\ Avenida San Miguel 3605, Talca, Chile. \\ ' Scuola Superiore Sant'Anna, Istituto di Scienze della Vita, Via Santa Cecilia 3, I-56127 Pisa, Italy. \\ d Universidad de Talca, Escuela Ingeniería Forestal, Avenida. Lircay s/n, Talca, Chile.
}

\begin{abstract}
SUMMARY
Energy crops have proved to be a viable alternative to fossil fuels. However, high biomass production always means that large quantities of nutrients from the soil are removed at harvest. The goal of this work was to estimate nutrient (nitrogen, phosphorous, potassium) use efficiency (NUE) and nitrogen balance in an eight-year-old Populus deltoides clone Lux, short rotation forestry under two cutting cycles, every two (biennial) and three (triennial) years, carried out under Mediterranean climate conditions. Results indicate that NUE, for all the analyzed elements, contained variations with slightly higher values for nitrogen and phosphorous in the triennial cycle. Although poplar cultivation has a positive nutrient efficiency, in terms of nitrogen, there is significant loss of this element in the crop cycle.
\end{abstract}

Key words: short rotation coppice, biomass, NUE.

\section{RESUMEN}

Los cultivos energéticos han demostrado ser una alternativa viable para la producción de energía a partir de la biomasa producida. Sin embargo, una alta producción de biomasa siempre significa que se eliminan grandes cantidades de nutrientes del suelo en la cosecha. El objetivo de esta investigación fue estimar la eficiencia en el uso de nutrientes (nitrógeno, fósforo y potasio) y el balance de nitrógeno en cultivos energéticos de Populus deltoides clon Lux bajo dos ciclos de corta (bienal y trienal), realizados en condiciones de clima mediterráneo. Los resultados indican que la eficiencia en el uso de nutrientes para todos los elementos analizados presenta variaciones contenidas con valores ligeramente superiores en trienal para el nitrógeno y el fósforo. Si bien el cultivo del álamo tiene una eficiencia nutritiva positiva, en términos de nitrógeno, existe una pérdida significativa de este elemento en el ciclo de cultivo.

Palabras clave: Cultivos de corta rotación, biomasa, NUE.

\section{INTRODUCTION}

Energy crops have proved to be a viable alternative to fossil fuels. Plants cultivated as short rotation coppices (SRCs) are characterized by high growth rate, adequate sprouting of the stool bed, and adaptation to sub-optimal environmental conditions (Berbec and Matica 2020). However, high biomass production always means that large quantities of nutrients from the soil are removed at harvest. Indeed, it has been observed that the short rotation coppice (SRC) of fast growing woody species has higher rates of nutrient removal by harvest than those presented by medium-rotation and mature forest (Toillon et al. 2016). The higher bark/wood ratio of younger stems in SRC systems and the higher nutrient concentration of the bark are important factors contributing to higher nutrient removal (Adler et al 2005). Furthermore, a high nutrient content of energy crops is a negative quality parameter in combustion as it raises the amount of ash to be handled, reduces biomass energy content and can give rise to harmful emissions, e.g. nitrogen oxides $\left(\mathrm{NO}_{x}\right)$ (Smith and Slater 2021). Nevertheless, in some cases, crops with low nutrient-use efficiency are preferable if removal of excess nutrients is aimed at (i.e. control of nutrient leaching). What is clear is 
that nutrients are removed when the plant is harvested. To ensure soil conservation and minimize the loss of soil nutrients, it is important to evaluate whether nutrients return properly to the soil. Nutrients return to the soil could be through the mineralization of organic matter or through the use of external inputs, such as fertilizers, among others. Furthermore, the nutrient content in the soil can vary due to phenomena such as plant uptake and harvest, leaching, runoff, erosion and denitrification. However, the evaluation of these processes is not easy to carry out.

In this context, nitrogen balance and nutrients use efficiency (NUE) can provide a first indication of nutrient dynamics in the system. Nitrogen balance considers the nitrogen provided by fertilizers, atmospheric inputs, mineralization and crop residues and the nitrogen lost by the harvested biomass and leaching. A simple definition for NUE, extensively employed for many agronomic and forest species, is the total harvestable biomass produced per unit of nutrient absorbed, which is equivalent to the reciprocal of nutrient concentration in the harvested biomass (Ferreira et al. 2021).

Several authors have used nutrient balance to evaluate the sustainability of biomass crops (Lodhiyal and Lodhiyal 1997, Heilman et al. 1997, Berthelot et al. 2000, Masoni and Pampana 2005, Weih et al. 2021). Lodhiyal and Lodhiyal (1997) reported, on a 4-year poplar plantation in India, nutrient return via leaf litter of $91 \pm 148 \mathrm{~kg} \mathrm{ha}^{-1}$ year $^{-1}$ of nitrogen, $8 \pm 15 \mathrm{~kg} \mathrm{ha}^{-1}$ year $^{-1}$ of phosphorous and $70 \pm$ $99 \mathrm{~kg} \mathrm{ha}^{-1}$ year ${ }^{-1}$ of potassium, with nitrogen use efficiency of 151-174 kg dry biomass $\mathrm{kg}^{-1} \mathrm{ha}^{-1}$ year $^{-1}$ of nitrogen. Total biomass production varied in a range of $122-1128 \mathrm{Mg}$ ha $^{-1}$. Berthelot et al. (2000) observed nutrient uptake of 92 , 15 and $87 \mathrm{~kg} \mathrm{ha}^{-1}$, of nitrogen, phosphorous and potassium, respectively, on a short rotation forestry of poplar in France, estimating nutrient return to soil of about 60 to $80 \%$ through leaf litter. In this case, total above-ground biomass reaches 88.8 and $74.7 \mathrm{Mg} \mathrm{ha}^{-1}$ dry matter. In another study, Heilman et al. (1997) evaluated nutrient content in several poplar clones managed in a 4-year cutting cycle, reporting ranges of 241-420, 41-105 and 159-288 $\mathrm{kg} \mathrm{ha}^{-1}$ of nitrogen, phosphorous and potassium, respectively.

Regarding NUE, Toillon et al. (2016), within an experiment in northern France with two contrasting site conditions and during two rotations in a wide set of $\mathrm{PO}$ pulus deltoides Marshall $x$ Populus nigra L. genotypes, obtained values of $118.3-632.7 \mathrm{~kg}$ yield dry matter per $\mathrm{kg}$ of applied nitrogen. Euring et al. (2016) examined the growth response and nitrogen use efficiency of different poplar species on shallow soil, suggesting that higher nitrogen uptake of poplar species might be an important adaptation to maintaining productivity under unfavorable soil conditions. Ceotto et al. (2016), in a study in Italy with poplar short rotation forestry, estimated that the agronomic efficiency of applied nitrogen varied from 5 to $14 \mathrm{~kg}$ of dry matter yield per kg of nitrogen applied. The recovery efficiency of the applied nitrogen $(\mathrm{kg}$ of nitrogen uptake per kg of nitrogen applied) was merely $7.3-10.6 \%$. The physiological efficiency of nitrogen uptake was $79-123 \mathrm{~kg}$ of dry matter yield per kilogram of nitrogen uptake.

Based on the hypothesis that the net nitrogen balance of SRC is positive, being the nitrogen that remains in the soil higher than the nitrogen removed, the goal of this work was to estimate nutrient (nitrogen, phosphorous, potassium) use efficiency and nitrogen balance in an SRC plantation of Populus deltoides clone Lux, carried out under Mediterranean climate conditions.

\section{METHODS}

Study area. The study was conducted at Centro di Ricerche Agro-ambientale (CIRRA) Enrico Avanzi at Pisa University (Italy). The experimental field was located in San Piero a Grado, $43^{\circ} 40^{\prime} \mathrm{N}$ and $10^{\circ} 21^{\prime} \mathrm{E}$ at $5 \mathrm{~m}$ above sea level and 2 $\mathrm{km}$ far from the sea. The soil was Xerofluvent (clay $20.1 \%$, silt $40.5 \%$, sand $39.4 \%$ ), typical of the lower River Arno, which is an alluvial plain characterized by a superficial water table ( $1.8 \mathrm{~m}$ deep in the driest conditions, having no influence on the movement of nutrients) and good nutrient availability (organic matter $1.8 \%$, total nitrogen content $1.3 \mathrm{~g} \mathrm{~kg}^{-1}$, available phosphorus $8.8 \mathrm{mg} \mathrm{kg}^{-1}$ and exchangeable potassium $128.3 \mathrm{mg} \mathrm{kg}^{-1}$ ). The plantation was established in 2000, on arable crop land, previously cultivated with wheat.

The average climate conditions of the site during the trial are shown in figure 1. During the experimental period (from 2000 to 2008), a considerable variability in rainfall was observed from year to year with mean annual rainfall of approximately $750 \mathrm{~mm}$ (from 655 to $936 \mathrm{~mm}$ ).

Experiment setup. The experiment began in early spring of 2000 , with the transplanting of 10,000 uprooted cuttings (about $20 \mathrm{~cm}$ long) per hectare of Populus deltoides (clone Lux). The planting layout was $2 \mathrm{~m}$ between rows and $0.5 \mathrm{~m}$ between plants. The soil was prepared ahead the planting season (October 1999) by deep plowing $(50 \mathrm{~cm})$, followed by sub soiling with ridge and plow. A pre-planting herbicide (Pendimentalin Click ${ }^{\circledR}$ 50, $3 \mathrm{~L} \mathrm{ha}^{-1}$ ) and a fertilization of $600 \mathrm{~kg} \mathrm{ha}^{-1}$ of a generic 8-24-24 (nitrogen - phosphorous - potassium) fertilizer were applied. The fertilizer doses were given systematically from the beginning of the trial and according to the agronomic management that was carried out in the area. In 2002, after the first harvest, the field was divided into two plots of $5,000 \mathrm{~m}^{2}$ each, assigned at two different cutting cycles: biennial (T2) and triennial (T3). Each cutting cycle was represented in an individual plot, being each plot the basis for future comparisons. T2 was harvested four times, in 2002, 2004, 2006 and 2008, while T3 three times, in 2002, 2005 and 2008. Harvesting occurred always at the end of February, before the vegetative regrowth, and was performed by a harvesting tookloader-chipper coupled with a trailer pulled by a tractor for the collection of chipped material. After each harvest, 


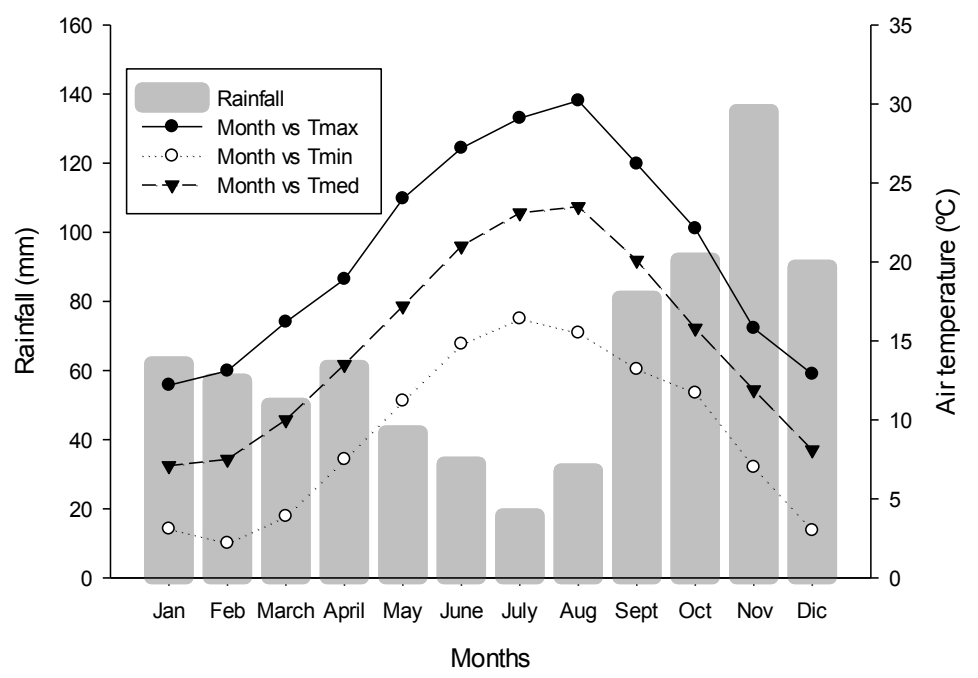

Figure 1. Average climate conditions at the field experimental site.

Condiciones climáticas medias en el área de estudio.

supplementary fertilization was applied, supplying $100 \mathrm{~kg}$ $\mathrm{ha}^{-1}$ of nitrogen as urea. At the end of the experiment (i.e. year 2008) the soil was recovered by removing stumps with a stump cutter and making deep plowing and sub soiling.

Biomass production. At every harvest, the fresh aboveground biomass of the whole plant was assessed. Data were collected in five transects $(5 \mathrm{~m}$ long, including 10 plants) per plot, which were always located within the three central rows of the plot. For each plant, fresh weight of stems, branches and leaves, height and their diameter at breast height were measured. Biomass subsamples of each plot were oven dried at $105^{\circ} \mathrm{C}$ (to constant mass) and dry matter content was determined. Total dry biomass was calculated by multiplying the average dry weight of the plants of each transects by plantation density. For dry weight, a Student's t-test was used to compare means under different treatments.

Nutrient use efficiency (NUE). In the laboratory, the elemental content of nitrogen, phosphorous and potassium of branches, stems and leaves was analyzed for each cutting cycle at the time of harvest (winter) during three years (2006, 2007 and 2008). The measurement of nitrogen in plant samples was carried out with the Kjeldhal-Tecator method (Lotti and Galoppini 1980), using the Kjeltec 2100 distiller (Foss, Italy), phosphorus using the methodology followed by Ames (1966), and potassium following Kalra (1998). The same plants used for the biomass production assessment were used for this purpose. A Student's t-test was used to compare means under different treatments. NUE was calculated according to Vitousek (1982) as:

$$
\text { NUE }=\text { Dry biomass }(\mathrm{g}) / \text { Nutrient content }(\mathrm{g})
$$

where 'Nutrient content' is the total nutrient quantity in aboveground woody tissue.

Nitrogen balance. Apparent nitrogen balance was also calculated using the method proposed by Masoni and Pampana (2005). The formula used to calculate nitrogen balance is as follows:

$$
\begin{aligned}
& \Delta \mathrm{N}=\text { Contributions (fertilizers }+ \text { atmospheric } \\
& \text { inputs }+ \text { mineralization }+ \text { crop residues) }- \text { Losses } \\
& \text { (nitrogen removed with the biomass collected }+ \\
& \text { leaching }+ \text { denitrification) }
\end{aligned}
$$

The proportion of nitrogen removed from the soil by leaching was estimated using historical data of agronomic tests carried out in the same location in San Piero A Grado (Masoni and Pampana 2005). Nitrogen volatilization was not considered, since in Italian soils do not seem to reach particularly significant levels (Masoni and Pampana 2005). In this work, the amount of nitrogen that remains in the soil contained in the poplar roots is not considered due to the impossibility of quantifying the amount of roots that decomposes during the SRC cycle. The crop residues of SRC are leaves. Thus, to assess the return to the soil of crop residues, 10 "traps" $\left(1 \mathrm{~m}^{2}\right)$ per plot were placed. Leaves were collected every 10 days from July to December. They were taken to the laboratory where they were dried in an oven at $60{ }^{\circ} \mathrm{C}$ until they had constant weight and dry matter content was determined.

To calculate the nitrogen removed with the biomass collected, the measurement of nitrogen in plant samples was carried out with the Kjeldhal-Tecator method (Lotti and Galoppini 1980), using the Kjeltec 2100 distiller (Foss, Italy); phosphorus, using the methodology followed 
by Ames (1966); and potassium, following Kalra (1998). Samples collected at the final harvest were analyzed from 15 plants per plot.

Most nitrogen in the soil is contained in the organic matter (e.g. humified), which on average contains $5 \%$ nitrogen. The organic matter of the soil is progressively decomposed and oxidized by microorganisms and atmospheric agents, therefore it releases the nitrogen it contains. According to Masoni and Pampana (2005), we assumed that soil humus is degraded with an average annual rate of $1 \%$. Thus, in the soil where the test was carried out, having an average organic matter content of $1.8 \%$, we estimated about $54 \mathrm{~kg}$ of nitrogen $\mathrm{ha}^{-1}$ year ${ }^{-1}$ released from the 50-cm-deep soil layer.

Atmospheric fixation brings different amounts of nitrogen to the soil depending on the amount of rainfall and their concentration of nitrogen. The latter presents discrete variations during the year, resulting higher in winter and more reduced in summer; however, in coastal Tuscany, it can be considered on average $2 \mathrm{mg}$ of nitrogen per liter (Masoni and Pampana 2005). Based on this value, the nitrogen supply from rainfall in the reference period of the test is shown in table 1 , with an average value of $15.7 \mathrm{~kg} \mathrm{ha}^{-1}$ year $^{-1}$.

According to Masoni and Pampana (2005), the nitrogen lost by denitrification does not reach consistent levels in normal Tuscany conditions and maximum loss of $5 \mathrm{~kg}$ ha $^{-1}$ of nitrogen per year can be estimated.

The factors that most influence nitrogen leaching are the magnitude and distribution of rainfall, the texture of the soil and its organic matter content, evapotranspiration, the dose of nitrogen fertilizer distributed, the type of fertilizer used and the time of distribution. Water is the vehicle through which nitric nitrogen moves in the ground and the leaching of nitrogen is therefore a phenomenon which, given the nitrates present, is strictly dependent on soil water balance (Masoni and Pampana 2005). The highest losses of

Table 1. Nitrogen from atmospheric precipitation.

Nitrógeno procedente de las precipitaciones atmosféricas.

\begin{tabular}{lcc}
\hline & \multicolumn{2}{c}{ Contributions deriving from precipitation } \\
\hline Year & Annual precipitation $(\mathrm{mm})$ & Nitrogen $\left(\mathrm{kg} \mathrm{ha}^{-1}\right.$ year $\left.^{-1}\right)$ \\
\hline 2000 & 897.2 & 17.9 \\
2001 & 720.2 & 14.4 \\
2002 & 1000.2 & 20.0 \\
2003 & 672.0 & 13.4 \\
2004 & 839.6 & 16.8 \\
2005 & 628.6 & 12.6 \\
2006 & 872.4 & 17.4 \\
2007 & 669.0 & 13.4 \\
Average & 787.4 & 15.7 \\
\hline
\end{tabular}

nitric nitrogen due to leaching occur in periods when rainfall is high and evapotranspiration and nitrogen uptake by plants is minimal, that is, in this environment, during autumn and winter. It should be pointed out that the leaching of nitrogen is an unavoidable phenomenon that occurs even in absence of nitrogen fertilization, since a certain quantity of nitrates is produced, of course, by the mineralization of the organic substance and by the oxidation of the ammonium ion, in every soil. The soil texture has a decisive importance in this case and the most fertile soils, richer in humus, and therefore in organic nitrogen, are those that present the highest losses. In the absence of nitrogen fertilization, for example, a medium-textured soil tending to clayey, well endowed with organic matter (2\%) may lose, during the period of wheat cultivation, more than $30 \mathrm{~kg} \mathrm{ha}^{-1}$ of nitrogen, which drops to $10 \mathrm{~kg} \mathrm{ha}^{-1}$ in loose and poor in organic matter soil (Masoni and Pampana 2005). In a hybrid poplar plantation in southwestern Michigan where soils are mesic Typic Hapludalfs developed on glacial outwash with high sand content $(\sim 76 \%$ in the upper 150 $\mathrm{cm}$ ) intermixed with more silt in the upper $50 \mathrm{~cm}$, Hussain et al. (2020) estimated nitrogen leaching of $31.87 \mathrm{~kg} \mathrm{ha}^{-1}$ year ${ }^{-1}$. For the soil where the experiments were carried out, leaching of $25 \mathrm{~kg} \mathrm{ha}^{-1}$ year ${ }^{-1}$ of nitrogen was estimated.

\section{RESULTS}

Biomass production. The annual average production in the study of the complete cycle of $P$. deltoides clone Lux differed between treatments, being $\mathrm{T} 3$ the most productive cutting cycle (figure 2). Lower yields in the period 2004-2006 may be because rainfall in that period was lower than the average rainfall. Biomass production in the full cycle $(8$ years) was 73.8 tons per hectare for T2 $\left(9.22 \mathrm{Mg} \mathrm{ha}^{-1}\right.$ year $\left.^{-1}\right)$ and 91.7 tons per hectare for T3 $\left(11.46 \mathrm{Mg} \mathrm{ha}^{-1}\right.$ year $\left.^{-1}\right)$.

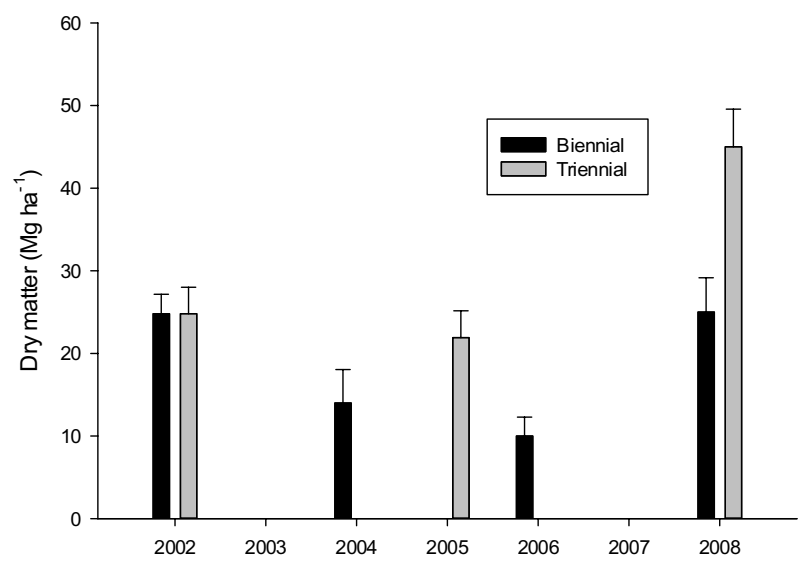

Figure 2. Populus deltoides clon Lux biomass production during the period 2000-2008.

Producción de biomasa en el período 2000-2008 de Populus deltoides clon Lux. 
On the other hand, the biomass of leaves returning to the soil is $1,132 \mathrm{~kg} \mathrm{ha}^{-1}$ year-1 for T2 and $575 \mathrm{~kg} \mathrm{ha}^{-1}$ year $^{-1}$ for T3.

Nutrient use efficiency. In the laboratory the elemental content of nitrogen, phosphorous and potassium of branches, stems and leaves was analyzed for each cutting cycle at the time of collection (figure 3). Comparing the two different cutting cycles, it can be appreciated that the concentration of main macro-nutrients, in general, is higher in T2 than in T3. The nutrients concentrated mainly in the branches with values of $10.8,1.38$ and $3.88 \mathrm{~g} \mathrm{~kg}^{-1}$ and $9.30,1.19$ and $3.61 \mathrm{~g} \mathrm{~kg}^{-1}$ of nitrogen, phosphorous and potassium respectively for T2 and T3. Instead, the concentrations of the main macro-nutrients in stems are smaller with a decrease of around $40 \%$ compared to that of branches.

Table 2 shows how the annual removals of the poplar SRC for both cutting cycles (T2 and T3), relative to the epigeal biomass at the time of harvest, differ in the different plant organs (branches and stems; leaves were not considered as removal because at the time of collection the plant had none).
T2

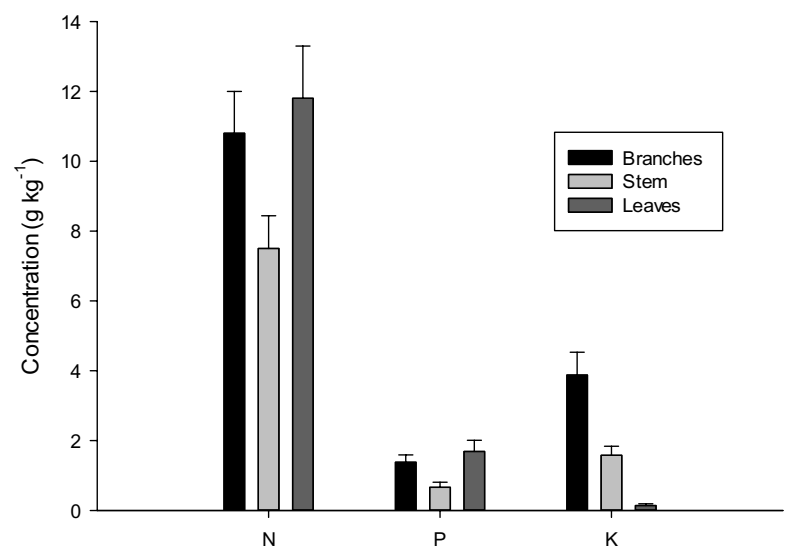

T3

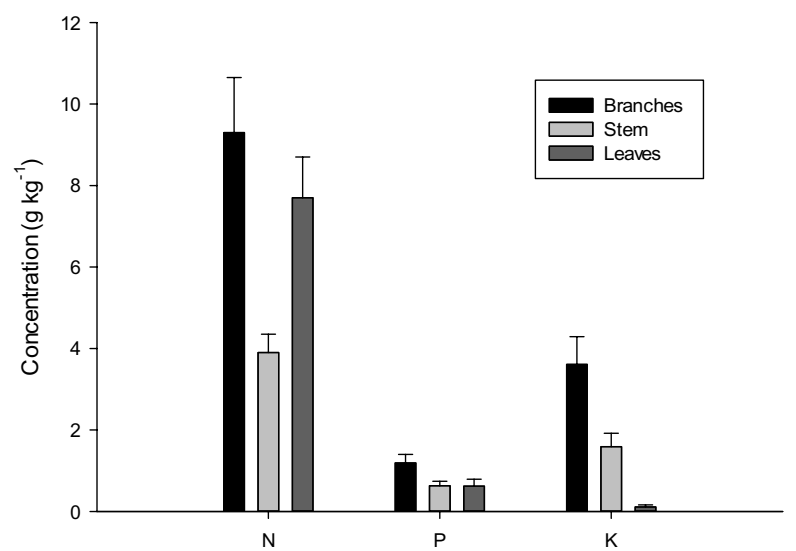

Figure 3. Average 2006, 2007 and 2008 nitrogen (N), phosphorous (P) and potassium (K) concentration in Populus deltoides clon Lux branches, stem and leaves with biennial (T2) and triennial (T3) cutting cycles.

Concentración media de nitrógeno $(\mathrm{N})$, fósforo $(\mathrm{P})$ y potasio $(\mathrm{K})$ en tronco, ramas y hojas de Populus deltoides clon Lux bienal (T2) y trienal (T3) en los años 2006, 2007, y 2008.

Table 2. Aboveground biomass removal of nitrogen $(\mathrm{N})$, phosphorous $(\mathrm{P})$ and potassium $(\mathrm{K})$ in the poplar SRC in an 8-year cycle (2000-2008) in biennial (T2) and triennial (T3) cutting cycles.

Remoción de nitrógeno $(\mathrm{N})$, fósforo $(\mathrm{P})$ y potasio $(\mathrm{K})$ de la biomasa aérea en la SRC de álamo en un ciclo de 8 años (2000-2008) con ciclos de corta bienales (T2) y trienales (T3).

\begin{tabular}{rrrrrrr}
\hline \multicolumn{7}{c}{$\mathrm{T} 2$} \\
\hline Year & $\mathrm{N}\left(\mathrm{kg} \mathrm{ha}^{-1}\right)$ & $\mathrm{P}\left(\mathrm{kg} \mathrm{ha}^{-1}\right)$ & $\mathrm{K}\left(\mathrm{kg} \mathrm{ha}^{-1}\right)$ & $\mathrm{N}\left(\mathrm{kg} \mathrm{ha}^{-1}\right)$ & $\mathrm{P}\left(\mathrm{kg} \mathrm{ha}^{-1}\right)$ & $\mathrm{K}\left(\mathrm{kg} \mathrm{ha}^{-1}\right)$ \\
\hline 2002 & 453.84 & 50.59 & 135.41 & 453.84 & 50.59 & 135.41 \\
2003 & - & - & - & - & - & - \\
2004 & 256.20 & 28.56 & 76.44 & - & - & - \\
2005 & - & - & - & 289.08 & 39.85 & 113.88 \\
2006 & 183.00 & 20.40 & 54.60 & - & - & - \\
2007 & - & - & - & - & - & - \\
2008 & 457.50 & 51.00 & 136.50 & 594.00 & 81.90 & 234.00 \\
\hline Total & $1,350.54$ & 150.55 & 402.95 & $1,336.92$ & 172.35 & 483.29 \\
\hline Mean & 150.06 & 16.73 & 44.77 & 148.55 & 19.15 & 53.70 \\
\hline
\end{tabular}


Nutrient use efficiency for both cutting cycles is shown in table 3. Comparing the two cutting cycles we can observe how NUE for all the analyzed elements show variations with higher values in $\mathrm{T} 3$ for nitrogen and phosphorous, differences regarding potassium were not significant. T2 has a lower value, that is, it produces less biomass for the same amount of nutrient removed.

Nitrogen balance. The nitrogen from the leaves that returned to the soil was included in the balance calculation. The amount of leaf that returned to the soil and the concentration of $\mathrm{N}$ in the leaves were known (figure 3). It is assumed that the annual quantity of fallen leaves is the same for all years of experimentation and the average value for 2006, 2007 and 2008 is considered $\left(1,132 \mathrm{~kg} \mathrm{ha}^{-1}\right.$ for T2 and $575 \mathrm{~kg} \mathrm{ha}^{-1}$ for T3). The amount of nitrogen returning to the soil is $13.4 \mathrm{~kg} \mathrm{ha}^{-1}$ for T2 and $4.4 \mathrm{~kg} \mathrm{ha}^{-1}$ for T3.

For the calculation of removal, it was assumed that the nitrogen content of the biomass collected after each cut is

Table 3. Nutrient use efficiency for poplar SRC subjected to biennial (T2) and triennial (T3) cutting cycles. In the same column, different letters stand for significant differences $(P \leq 0.05)$.

Eficiencia en el uso de nutrientes en una SRC de álamo con ciclos de corta bienales (T2) y trienales (T3).

\begin{tabular}{cccc}
\hline & \multicolumn{3}{c}{ Nutrient Use Efficiency $\left(\mathrm{g}_{\text {dry biomass }} \mathrm{g}_{\text {nutrient }}{ }^{-1}\right)$} \\
\cline { 2 - 4 } & NUE $(\mathrm{N})$ & NUE $(\mathrm{P})$ & NUE $(\mathrm{K})$ \\
\hline $\mathrm{T} 2$ & $54.64^{\mathrm{b}}$ & $490.20^{\mathrm{b}}$ & $183.15^{\mathrm{a}}$ \\
$\mathrm{T} 3$ & $75.76^{\mathrm{a}}$ & $549.45^{\mathrm{a}}$ & $192.31^{\mathrm{a}}$ \\
\hline
\end{tabular}

the average of 2006, 2007 and 2008 nitrogen content for T2 and for T3 for all the harvests of the crop cycle (table 2).

Data used to calculate the nitrogen balance are summarized as follows:

$\Delta \mathrm{N}=$ Contributions [Fertilizers $\left(48 \mathrm{~kg}\right.$ of nitrogen $\mathrm{ha}^{-1}$ in 2000 and $100 \mathrm{~kg}$ of nitrogen $\mathrm{ha}^{-1}$ after each harvest) + Atmospheric Inputs (table 1) + Mineralization $(50 \mathrm{~kg}$ of nitrogen $\mathrm{ha}^{-1}$ year $\left.^{-1}\right)+$ crop residues $(13.4$ and $4.4 \mathrm{~kg}$ of nitrogen ha ${ }^{-1}$ year $^{-1}$ for T2 and T3)] - Losses [nitrogen removed with the biomass collected (table 2) + leaching $\left(25 \mathrm{~kg}\right.$ of nitrogen $\mathrm{ha}^{-1}$ year $\left.^{-1}\right)+$ denitrification $(5 \mathrm{~kg}$ of nitrogen $\mathrm{ha}^{-1}$ year $\left.^{-1}\right)$ ]

Starting from the data presented above, in table 4 the result of the nitrogen balance for the poplar SRC (T2 and T3) is shown.

From results shown in table 4 , it emerges that at the end of the 8-year life cycle of poplar, short rotation forestry appears to have a decrease in the amount of nitrogen in the system for both cutting cycles. The quantity lost is higher in T3 than in T2 as T2 has a superior number of fertilizations carried out following each coppicing.

\section{DISCUSSION}

Biomass production. This long-term trial revealed that different harvesting cycles can affect biomass yield (Cabrera et al. 2014). The results in this study are consistent with most of the available data, which indicate a strong relationship between the cutting cycle and the productivity of the stand. In fact, for biannual cutting cycles Rafaschieri et al. (1999) obtained variable yields between 16 and 20

Table 4. Nitrogen balance for the poplar SRC subjected to biennial (T2) and triennial (T3) cutting cycles (2000-2008).

Balance de Nitrógeno en una SRC de álamo con ciclos de corta bienales (T2) y trienales (T3) (2000-2008).

\begin{tabular}{|c|c|c|c|c|c|c|}
\hline \multirow[t]{2}{*}{ Year } & \multicolumn{2}{|c|}{$\begin{array}{c}\text { Contributions } \\
\left(\mathrm{kg} \mathrm{ha}^{-1} \text { of nitrogen }\right)\end{array}$} & \multicolumn{2}{|c|}{$\begin{array}{c}\text { Removal } \\
\text { (kg ha-1 of nitrogen) }\end{array}$} & \multicolumn{2}{|c|}{$\begin{array}{l}\text { Contributions - Removal } \\
\left.\text { (kg ha }{ }^{-1} \text { of nitrogen }\right)\end{array}$} \\
\hline & $\mathrm{T} 2$ & $\mathrm{~T} 3$ & $\mathrm{~T} 2$ & $\mathrm{~T} 3$ & $\mathrm{~T} 2$ & $\mathrm{~T} 3$ \\
\hline 2000 & 115.9 & 115.9 & 30.0 & 30.0 & 85.9 & 85.9 \\
\hline 2001 & 77.8 & 68.8 & 30.0 & 30.0 & 47.8 & 38.8 \\
\hline 2002 & 183.4 & 174.4 & 453.8 & 483.8 & -270.4 & -309.4 \\
\hline 2003 & 76.8 & 67.8 & 30.0 & 30.0 & 46.8 & 37.8 \\
\hline 2004 & 180.2 & 71.2 & 286.2 & 30.0 & -106 & 41.2 \\
\hline 2005 & 76.0 & 167.0 & 30.0 & 289.1 & 46.0 & -122.1 \\
\hline 2006 & 180.8 & 71.8 & 213.0 & 30.0 & -32.2 & 41.8 \\
\hline 2007 & 76.8 & 67.8 & 30.0 & 30.0 & 46.8 & 37.8 \\
\hline 2008 & 179.1 & 170.1 & 487.5 & 624.0 & -308.4 & -453.9 \\
\hline Total & $1,146.8$ & 974.8 & $1,590.54$ & $1,576.92$ & -443.74 & -602.12 \\
\hline
\end{tabular}


$\mathrm{Mg} \mathrm{ha}{ }^{-1}$ year $^{-1}$ for short cutting cycles varying between three and five years. Kauter et al. (2003), using Populus sp., obtained between 10 and $12 \mathrm{Mg} \mathrm{ha}^{-1}$ year ${ }^{-1}$ yield. For longer rotations, biomass yields were sometimes consistent with several cases reported in literature (Kopp et al. 2001) although slightly higher compared with others (Laureysens et al. 2005). Regarding leaves biomass, there are usually differences in the production of leaves and therefore their biomass, when planting densities vary, though, this is not the case here. Data collected in the field have yielded these results.

Nutrient use efficiency. The nutrient cycle in a forest ecosystem is one of the main processes that support the production of organic matter (Lodhiyal and Lodhiyal 1997). For the calculation of the use efficiency of the main macro-nutrients (nitrogen, phosphorous and potassium), already used by other authors (Karacic and Weih 2006), it is necessary to know the amount of nutrients that have been removed from the crop and the production of biomass. Comparing the two different cutting cycles, the quantity of the main macro-nutrients is higher in T2 than in T3, confirming what has already been observed by Lodhiyal and Lodhiyal (1997), concerning the decrease in nutrient content as a function of plant age. Nutrient concentrations in biomass components varied with the component considered, plantation age (the concentrations of most nutrients, except carbon, tended to decrease) and genetic material (Rodríguez-Soalleiro et al. 2018). In addition to the distribution among the different organs following the fall of leaves, there is a migration of nutrients from leaves to branches, stems and roots (Lodhiyal and Lodhiyal 1997).

The annual removals of the poplar SRC for both cutting cycles (T2 and T3), relative to the aboveground biomass at the time of harvest, differ in the different plant organs (branches and stems; leaves were not considered as removal at the time of collection, the plant had none). Values obtained are in line with other results reported in literature. For example, Adegbidi et al. (2001), in a trial carried out in North America, reported values of 71, 11.3 and $45 \mathrm{~kg}$ $\mathrm{ha}^{-1}$ year $^{-1}$, respectively for nitrogen, phosphorous and potassium. Jug et al. 1999, in a trial with several poplar and willow clones, reported poplar and willow removal in SRC with a five-year cutting cycle equal to 90-270, 15-45 and $30-180 \mathrm{~kg} \mathrm{ha}^{-1}$, respectively for nitrogen, phosphorous and potassium. Swamy et al. (2006) observed an export of 25.5-33.6 kg of nitrogen ha ${ }^{-1}$ year $^{-1}$ in a 6-year P. deltoides plantation using different amount of fertilizers. Toillon et al. (2016) suggested that the range of variation observed in terms of the amount of nitrogen exported at the end of each rotation for Populus plantations varied from 3.5-62.6 $\mathrm{kg}$ of nitrogen $\mathrm{ha}^{-1}$ year ${ }^{-1}$ for the first rotation and 2.8-46.7 $\mathrm{kg}$ of nitrogen $\mathrm{ha}^{-1}$ year $^{-1}$ for the second one. Finally, Calfapietra et al. (2007) observed that nitrogen pools of stems and branches over 3 years in Populus plantations ranged between 280 and $440 \mathrm{~kg}$ of nitrogen ha ${ }^{-1}$.

Nutrient use efficiency is a parameter that plays a key role for each type of crop, on the one hand, nutritional requirements are an important voice of growing costs in monetary and energy terms, and on the other hand, high nutritional requirements and therefore elevated input necessarily lead to a more significant environmental cost. In particular, for energy crops, this parameter must necessarily be high to guarantee lower energy costs and a higher level of quality of the biomass produced, as a high content of nutrients has negative effects on the calorific value, increases the content in ash and can generate high amounts of polluting emissions. Fertilization is one of the largest expenses in a poplar crop, reaching as high as $27 \%$ of all costs (Manzone et al. 2009). It is therefore important to determine the lowest dose that produces the highest yields to make more efficient use of supplies and economic viability. In the case of this study, NUE values are not high if we compare them with other studies (table 5), this implies that

Table 5. Nutrient use efficiency of some species.

Eficiencia en el uso de nutrientes de algunas especies.

\begin{tabular}{|c|c|c|c|c|}
\hline \multirow[b]{2}{*}{ Species } & \multicolumn{3}{|c|}{ Nutrient use efficiency $\mathrm{g} \mathrm{g}^{-1}$} & \multirow{2}{*}{ Reference } \\
\hline & Nitrogen & Phosphorous & Potassium & \\
\hline \multirow[t]{2}{*}{ Miscanthus } & 200 & 1580 & 80 & Beale and Long 1997 \\
\hline & 135 & 526 & 78 & Lewandowski and Schmidt 2006 \\
\hline Populus & $145-370$ & $1000-2000$ & $256-370$ & Jug et al. 1999 \\
\hline Salix & $152-244$ & $909-1429$ & $323-500$ & Jug et al. 1999 \\
\hline Eucalypthus & 219 & 3477 & 427 & Lodhiyal and Lodhiyal 1997 \\
\hline Phalaris & $43-78$ & $278-385$ & $40-76$ & Geber 2000 \\
\hline Maize & $66-111$ & $333-556$ & $86-161$ & Beale and Long 1997 \\
\hline Wheat & $83-87$ & - & $117-133$ & Jorgensen 2000 \\
\hline
\end{tabular}


the applied fertilizer doses have not been optimal and the agronomic management would have to be changed.

NUE in T2 has a lower value, that is, it produces less biomass for the same amount of nitrogen removed. Other authors (Lodhiyal and Lodhiyal 1997) observed the same trend in their experiments, with values equal to 159,1407 and $307 \mathrm{~kg}$ of biomass produced per kg of nutrients removed respectively for nitrogen, phosphorous and potassium in T2 and values equal to 172,1455 and 318 for nitrogen, phosphorous and potassium respectively in T3. Calfapietra et al. (2007) in a 3-year P. alba plantation observed a NUE of 120-130 kg dry matter per kg of nitrogen in an unfertilized soil. According to Hernández et al. (2009), nitrogen has relatively low NUE due to its high concentration in green leaves and to internal translocation. Other investigations with similar results are those carried out by Laclau et al. (2000) in Eucalyptus SRC. In other research, Medeiros et al. (2020), assess the effects of planting density on nutrient use efficiency (NUE) in the production of biomass of a hybrid of Eucalyptus urophylla $\times$ Eucalyptus grandis. Increase in planting density resulted in higher NUE for wood production. The increase in NUE indicates a possible nutritional deficit in trees at higher stocking rates at the age of three years. The higher the planting density, the sooner the site will require re-fertilization. Regarding potassium, previous research has shown that potassium use efficiency declined with an increase in the availability of the nutrient (Silva et al. 2002), with authors inferring that plants tend to absorb higher amounts of this nutrient as its concentration increases in soil and, because this uptake exceeds the growth rate, nutritional efficiency declines.

Comparing what has been reported so far with results inherent to other species proposed as crops dedicated to energy use (table 5), it emerges that the efficiency in the use of nutrients is similar with regard to tree species, except in the case of efficiency of the use of phosphorous, which, in the case of eucalyptus, is considerably higher than in other tree species. Comparing instead the results obtained with those of perennial and annual herbaceous species, the efficiency in the use of nutrients is always better in the case of tree species.

Nitrogen balance. As it emerges from the results obtained, and taking into account that the nitrogen of the belowground organs of poplars is estimated at about $200 \mathrm{~kg}$ per hectare in an 11-year-old plantation (Martani et al. 2021), for both cutting cycles, there is loss of nitrogen in the system. In this sense, it is very important to evaluate the fertilization doses that should be used, since otherwise, we would be decreasing the amount of nitrogen available for the correct growth of the plant. These results are in line with those of Calfapeitra et al. (2007) that found an important decrease in soil $\mathrm{N}$ concentration at the end of the first crop rotation of Populus spp. On the other hand, results differ from those reported by Lodhiyal and Lodhiyal (1997) that suggest that the shorter rotation cycle, combined with the high density of trees, may help in keeping the soil nutrient level intact, as nutrient return through litter fall approximately compensates for depletion through nutrient uptake from the soil. They also suggest that one advantage of a short rotation cycle of a dense poplar plantation is to produce more dry matter without too much use of nutrients. Toillon et al. (2016) suggest an important fact to take into account when performing the nitrogen balance and that is that the most productive and efficient genotypes to use nitrogen were also responsible for the highest nitrogen exports during harvest. It has been reported that the rate of nitrogen uptake of poplars may vary during plant development as well as among poplar species and sites. Furthermore, several studies reported that drought stress related genes are significantly regulated at the transcription level by nitrogen fertilization or starvation, suggesting that nitrogen metabolism is linked to stress tolerance (Euring et al. 2016).

\section{CONCLUSIONS}

The goal of this investigation was to estimate nutrient (nitrogen, phosphorous, potassium) use efficiency and nitrogen balance in a SRC plantation of Populus deltoides clone Lux, carried out in San Piero A Grado (Pisa, Italy). Regarding nutrient use efficiency, we can conclude that T3 is more efficient than $\mathrm{T} 2$ for the macronutrients analyzed. Regarding nitrogen balance, we can conclude that the hypothesis raised is rejected, the nitrogen that remains in the soil is lower than the nitrogen removed. The poplar SRC is one of the most promising woody species that can be grown in a temperate climate. It has been proven in different studies that the production of energy from the biomass generated has a positive energy balance. However, when it comes to nutrient use and nitrogen balance, more attention needs to be paid. Although poplar cultivation has a positive nutrient use efficiency, in terms of nitrogen, there is a significant loss of this element in the crop cycle. Anyway, it is necessary to deepen more in this type of studies to make an efficient fertilization and not deplete the soil and its resources.

The results available so far highlight how biomass crops could deliver an important service to maintaining soil fertility, however further investigation is needed to assess their actual nutritional requirements as well as nutrient use efficiency and the effect of their cultivation on soil nutrient status in the long term.

\section{REFERENCES}

Adegbidi HG, TA Volk, EH White, LP Abrahamson, RD Briggs, DH Bickelhaupt. 2001. Biomass and nutrient removal by willow clones in experimental bioenergy plantations in New York State. Biomass and Bioenergy 20:399-411. DOI: 10.1016/S0961-9534(01)00009-5

Adler A, T Verwijst, P Aronsson. 2005. Estimation and relevance of bark proportion in a willow stand. Biomass and Bioenergy 29(2):102-113. DOI: 10.1016/j.biombioe.2005.04.003. 
Ames B. 1966. Assay of inorganic phosphate, total phosphate and phosphatases. In Neufeld EF, V Ginsburg eds. Methods enzymology. Academic Press, Boca Raton. p. 115-118.

Beale CV, SP Long. 1997. Seasonal dinamics of nutrient accumulation and partitioning in the perennial $\mathrm{C}_{4}$-grasses Miscanthus $x$ giganteus and Spartinia Cynosuroides. Biomass and Bioenergy 12:419-428. DOI: 10.1016/S09619534(97)00016-0

Berbeć AK, M Matyka. 2020. Planting Density Effects on Grow Rate, Biometric Parameters, and Biomass Calorific Value of Selected Trees Cultivated as SRC. Agriculture 10(12):583. DOI: 10.3390 /agriculture10120583

Berthelot A, J Ranger, D Gelhaye. 2000. Nutrient uptake and immobilization in a short rotation coppice stand of hybrid poplars in north-west France. Forest Ecology and Management 128:167-179. DOI: 10.1016/S03781127(99)00145-0

Cabrera A, C Tozzini, S Espinoza, R Santelices, E Bonari. 2014. Cálculo del balance energético de una plantación de Populus deltoides clon Lux con fines energéticos en un sitio con ambiente mediterráneo. Bosque 35(2):133-139. DOI: $10.4067 / \mathrm{S} 0717-92002014000200001$

Calfapietra C, P De Angelis, B Gielen, M Lukac, MC Moscatelli, G Avino, A Lagomarsino, A Polle, R Ceulemans, G Scarascia-Mugnozza, MR Hoosbeek, MF Cotrufo. 2007. Increased nitrogen-use efficiency of a short-rotation poplar plantation in elevated $\mathrm{CO}_{2}$ concentration. Tree Physiology 27:1153-1163. DOI: 10.1093/treephys/27.8.1153

Ceotto E, F Castelli, A Moschella, M Diozzi, M Di Candilo. 2016. Poplar short rotation coppice is not a first choice crop for cattle slurry fertilization: Biomass yield and nitrogen-use efficiency. Industrial crops and products 85:167-173. DOI: 10.1016/j.indcrop.2016.02.042

Euring D, S Ayegbeni, M Jansen, J Tu, C Gomes Da Silva, A Polle. 2016. Growth performance and nitrogen use efficiency of two Populus hybrid clones (P. nigra $\times$ P. maximowiczii and $P$. trichocarpa $\times P$. maximowiczii) in relation to soil depth in a young plantation. iForest 9:847-854. DOI: $\underline{10.3832 / \text { ifor2016-009 }}$

Ferreira G, B Rau, D Aubrey. 2021. Temporal nitrogen dynamics in intensively managed loblolly pine early stand development. Forest Ecology and Management 483:118890. DOI: $10.1016 /$ j.foreco.2020.118890

Geber U. 2000. Nutrient removal by grasses irrigated with wastewater and nitrogen balance for reed canarygrass. Journal of environmental quality 29:398-406. DOI: 10.2134/ jeq2000.00472425002900020005x

Heilman PE, R Norby. 1997. Nutrient cycling and fertility management in temperate short rotation forest systems. Biomass and Bioenergy 14:361-370. DOI: 10.1016/S09619534(97)10072-1

Hernández J, A del Pino, L Salvo, G Arrarte. 2009. Nutrient export and harvest residue decomposition patterns of a Eucalyptus dunnii Maiden plantation in temperate climate of Uruguay. Forest Ecology and Management 258:92-99. DOI: $10.1016 /$ j.foreco.2009.03.050

Hussain MZ, GP Robertson, B Basso, SK Hamilton. 2020. Leaching losses of dissolved organic carbon and nitrogen from agricultural soils in the upper US Midwest. Science of The Total Environment 734:139379. DOI: 10.1016/j. scitotenv.2020.139379
Jorgensen U. 2000. Wheat rye and triticale for energy- input, yield and quality. In Jorgensen U ed. Do energy crop have a future in Denmark? DJF rapport Markbrug 29:6-11.

Jug A, C Hofmann-Schielle, F Makeschin, KE Rehfuess. 1999. Short-rotation plantations of balsam poplar, aspen and willows on former arable land in the Federal Republic of Germany. II Nutritional status and bioelement export by harvested shoot axes. Forest Ecology and Management 121:67-83. DOI: 10.1016/S0378-1127(98)00557-X

Kalra YP. 1998. Handbook of reference methods for plant analysis. Soil and Plant Analysis Council, Inc. CRC Press, USA. 300 p. DOI: $10.1201 / 9780367802233$

Karacic A, M Weih. 2006. Variation growth and resource utilisation among eight poplar clones grown under different irrigation and fertilisation regimes in Sweden. Biomass and Bioenergy 30:115-124. DOI: 10.1016/j.biombioe.2005.11.007

Kauter D, I Lewandowski, W Claupein. 2003. Quantity and quality of harvestable biomass from Populus short rotation coppice for solid fuel use-a review of the physiological basis and management influences. Biomass and Bioenergy 24:411-427. DOI: 10.1016/S0961-9534(02)00177-0

Kopp R, L Abrahamson, E White, T Volk, C Nowak, R Fillhart. 2001. Willow biomass production during ten successive annual harvests. Biomass and Bioenergy 20:1-7. DOI: 10.1016/S0961-9534(00)00063-5

Laclau JP, JP Bouillet, J Ranger. 2000. Dynamics of biomass and nutrient accumulation in a clonal plantation of Eucalyptus in Congo. Forest Ecology and Management 128:181-196. DOI: 10.1016/S0378-1127(99)00146-2

Laureysens I, A Pellis, J Willems, R Ceulemans. 2005. Growth and production of a short rotation coppice culture of poplar. III. Second rotation results. Biomass and Bioenergy 29:1021. DOI: $10.1016 /$ j.biombioe.2005.02.005

Lewandowski I, U Schmidt. 2006. Nitrogen, energy and land use efficiencies of miscanthus, reed canary grass and triticale as determined by the boundary line approach. Agriculture Ecosystem and Environment 112:335-346. DOI: 10.1016/j. agee.2005.08.003

Lodhiyal LS, N Lodhiyal. 1997. Nutrient cycling and nutrient use efficiency in short rotation, high density Central Himalayan Tarai poplar plantation. Annals of botany 79:517-527. DOI: $\underline{10.1006 / \text { anbo.1996.0374 }}$

Lotti G, C Galoppini. 1980. Guida alle analisi chimico agrarie: esercitazioni di chimica analitica, industrie agrarie e chimica agraria. Bologna Italia. Edagricole. 434 p.

Manzone M, G Airoldi, P Balsari. 2009. Energetic and economic evaluation of a poplar cultivation for the biomass production in Italy. Biomass and Bioenergy 33:1258-1264. DOI: 10.1016/j.biombioe.2009.05.024

Martani E, A Ferrarini, P Serra, M Pilla, A Marcone, S Amaducci. 2021. Belowground biomass $\mathrm{C}$ outweighs soil organic $\mathrm{C}$ of perennial energy crops: Insights from a long-term multispecies trial. GCB Bioenergy 13:459-472. DOI: $10.1111 /$ gcbb. 12785

Masoni A, S Pampana. 2005. Fertilizzazione azotata dei cereali autunno-vernini. Venturina, Italy. Irrigazione e Risparmio Risorsa Idrica. 20 p.

Medeiros PL, GGC Silva, EMM Oliveira, CO Ribeiro, JMS Silva, AS Pimenta. 2020. Efficiency of nutrient use for biomass production of a Eucalyptus clone as a function of 
planting density in short-rotation cropping. Australian Forestry 83(2):66-74. DOI: 10.1080/00049158.2020.1774958

Rafaschieri A, M Rapaccini, G Manfrida. 1999. Life Cycle Assessment of electricity production from poplar energy crops compared with conventional fossil fuels. Energy Conversion and Management 40:1477-1493. DOI: 10.1016/S0196-8904(99)00076-X

Rodríguez-Sollaeiro R, C Eimil-Fraga, E Gómez-García, J García-Villabrille, A Rojo-Alboreca, F Muñoz, N Oliveira, H Sixto, C Pérez-Cruzado. 2018. Exploring the factors affecting carbon and nutrient concentrations in tree biomass components in natural forests, forests plantations and short rotation forestry. Forest Ecosystems 5:35. DOI: 10.1186/ s40663-018-0154-y

Silva SR, NF Barros, RF Novais, PRG Pereira. 2002. Eficiência nutricional de potássio e crescimento de eucalipto influenciados pela compactação do solo. Revista Brasileira de Ciência do Solo 26:1001-1010. DOI: 10.1590/S0100$\underline{06832002000400018}$

Smith R, F Slater. 2010. The effects of organic and inorganic fertilizer applications to Miscanthus $\times$ giganteus, Arundo donax and Phalaris arundinacea, when grown as energy crops in Wales, UK. GCB Bioenergy 2:169-179. DOI: 10.1111/j.1757-1707.2010.01051.x

Swamy SL, A Mishra, S Puri. 2006. Comparison of growth, biomass and nutrient distribution in five promising clones of Populus deltoides under an agrisilviculture system. Bioresource Technology 97:57-68. DOI: 10.1016/j.biortech.2005.02.032

Toillon J, E Dallé, G Bodineau, A Berthelot, JC Bastien, F Brignolas, N Marron. 2016. Plasticity of yield and nitrogen removal in 56 Populus deltoides $x$ P. nigra genotypes over two rotations of short-rotation coppice. Forest ecology and Management 375:55-65. DOI: 10.1016/j.foreco.2016.05.023

Vitousek P. 1982. Nutrient cycling and nutrient use efficiency. American Naturalist 119:553-572.

Weih M, NE Nordh, S Manzoni, S Hoeber. 2021. Functional traits of individual varieties as determinants of growth and nitrogen use patterns in mixed stands of willow (Salix spp.). Forest Ecology and Management 479:118605. DOI: 10.1016/j.foreco.2020.118605

Recibido: $24 / 11 / 20$

Aceptado: 21/06/21 